\title{
In vitro effect of aqueous extract of fresh cassava leaves (Manihot esculenta, Crantz) on the larvae of Haemonchus contortus as an intestinal parasite of sheep.
}

Ana Flávia Lopes Medeiros ( $\square$ anaflavialmvet@gmail.com )

UNIDERP https://orcid.org/0000-0002-9232-8665

Marney Pascoli Cereda Cereda

Agronomist https://orcid.org/0000-0002-8181-7754

Gabriel Furrer Matos Braz

https://orcid.org/0000-0002-0584-7986

\section{Method Article}

Keywords: Linamarin, Cyanogenic compounds, Fresh leaves, Lethal dose, Animal food, Anthelmintic, Active compounds, Free cyanide

Posted Date: November 5th, 2021

DOI: https://doi.org/10.21203/rs.3.rs-1025015/v2

License: (c) (i) This work is licensed under a Creative Commons Attribution 4.0 International License.

Read Full License 


\section{Abstract}

Cassava is frequently fed to animals. In the case of sheep, the producer relates consumption to a reduction in the parasite load. The literature has proven the effect of phenolic compounds as an anthelmintic in vivo, but no evidence for cyanogenic compounds, also present in all parts of the cassava plant, was found. A controlled in vitro bioassay was used to evaluate the aqueous extract of fresh cassava leaves. The efficiency parameter was the immobility of Haemonchus contortus larvae at the L3 stage, also used to evaluate commercial anthelmintics. Cell culture plates with 100 active L3-stage larvae per well were used, being each replicate constituted by three wells. Aqueous extract of fresh cassava leaves (FCL), Ivomec ${ }^{\circledR} 0.01 \%(\mathrm{PCl})$ as the positive control, and distilled water as negative control (NCW), were placed in the culture plate wells. Considering the immobility of the larvae as a positive anthelmintic effect, the results showed that in NCW treatments all larvae were mobile, while in PCl all 300 larvae were immobile. FCL produced a gradient of larval inactivation correlation $\left(R^{2} 0.996\right)$. The best-fit equation was $y=-33.39 \ln (x)+40.517$, a logarithmic equation, which allowed the calculation of the Lethal Concentration (CL) of $3.44 \mu \mathrm{g} \mathrm{CN}-\mathrm{ml}$, or $80.0 \mathrm{mg}$ of fresh cassava leaves per milliliter of water, with a performance equivalent to ivermectin. This concentration of free cyanide is compatible with the safe consumption of fresh leaves by live weight of sheep. The exact amount of cassava roots, leaves, or shoots, consumed to provide an effective dose for controlling $H$. contort should be established in vivo. Although phenolic compounds must also be present in the extract, the immobility was attributed to cyanogenic compounds since the correlation was proportional to the increase in the cyanide concentration. It can be concluded that the consumption of fresh cassava leaves has the potential as an anthelmintic agent to be evaluated in vivo by feeding sheep and goats. Local use could also add value to the production of fresh cassava leaves, with an average potential production of 2.5 tonnes ha-1 ${ }^{-1}$, available throughout the year, with greater production at the beginning of cultivation and in the summer months. These leaves could be used after the roots harvesting or even after pruning for this purpose. Currently, this amount of good quality protein material remains without use in the field.

\section{Introduction}

Parasites are a limiting factor in raising sheep and goats. As stated by Kamaraj \& Rahuman (2010), research on plants with anthelmintic potential has been carried out for years as alternative methods of controlling populations of parasites, mainly gastrointestinal, due to the resistance to traditional commercial compounds.

Among the main parasites present in sheep farming, Haeconchus contortus, a hematophagous parasite present in the abomasum of sheep, has been developing parasitic resistance to commercial compounds. This parasite is a powerful hematophagous, feeding up to $0.05 \mathrm{ml}$ of blood per day, causing lesions on the inner wall of the abomasum, in addition to anemia, diarrhea, emaciation, edema, supine position, and severe weakness, becoming a large problem in the production of these animals, as it impacts their performance and can lead to their death (Brik, et al. 2019). 
Controlling sheep parasites with plants has already been considered by several researchers and sheep breeders. Some examples of these plants are Senegalia gaumeri (Castanheda-Ramirez, et al. 2017), Artemisia annua (Squires, 2010), Melastoma malabatricum (Suteky and Ji, 2019), Musa paradisiaca (Marie-Magdeleine et al. 2014), and Leucaena leucocephala and Cajanaus cajan (Minatchy et al. 2020). Each of these plants is rich in compounds known for their anthelmintic potentials, such as condensed tannins, total phenols, and total tannins (Castañeda-Ramírez, et al. 2017).

Cassava (Manihot esculenta) has also been considered by several authors as an anthelmintic (Sokerya, 2009; Marie-Magdeleine et al, 2010; Al-Rofaai et al (2010); Minatchy et al 2020). Some studies are carried out directly on the parasitized animals by including the plant in their feed (Sokerya, 2009; Minatchy et al, 2020) and others are carried out in vitro, observing its effects on eggs, larvae, and adults (MarieMagdeleine et al, 2010; Kamaraj \& Rahuman, 2010). These studies have shown promise concerning the anthelmintic effect of cassava, and researchers usually attribute this result to the presence of tannins in the plant. However, researchers have not furthered their research into the effect of cyanogenic glycosides such as linamarin and lotaustrarin, which are relevant to cassava (Ravindran, 1995).

When consumed by animals, cyanogenic glycosides are processed by enzymes present in the plant itself and by cellulosic microorganisms in the rumen, and the cyanide is then released into the body, which may or may not trigger intoxication (Gensa, 2019). Literature proves tolerance to $2.0-6.0 \mathrm{mg} \mathrm{HCN} \mathrm{kg}^{-1}$ of fresh leaves per live weight for ruminants, which is explained by the presence of sulfur-based compounds in their feeds, which in contact with $\mathrm{HCN}$ forms the thiocyanate, which is released in the urine, promoting detoxification (Onwuka et al, 1992).

Sokerya, (2009) obtained promising results regarding the use of fresh leaves and cassava silage with a reduction of eggs present in the animals' feces. In their experiment, the author highlighted the presence of $\mathrm{HCN}$, within the limit for animal consumption, but did not attribute the anthelmintic effect to cyanide, as the target was phenolic compounds, and only highlighted the reduction from $585 \mathrm{mg}$ to $170 \mathrm{mg}$ of HCN by the ensiling process.

Due to the lack of information on the effect of water-extracted cyanogenic compounds, an in vitro protocol was tested to verify the effect of the aqueous extract of fresh cassava leaves (Manihot esculenta) on the mobility of $H$. contortus larvae at the L3 stage, as well as the amount of cyanide needed to reach the Lethal Dose under these circumstances.

\section{Material And Methods.}

Obtaining cassava leaf extract: cassava leaves were collected from the cassava cultivar Paraguainha, a traditional and commercial cultivar, widely used in the Central West region of Brazil. The leaves were washed, dried with paper towels, and weighed. Then, the leaves were immediately macerated with distilled water, obtaining an extract with a concentration of $80 \mathrm{mg}$ of leaves for each $\mathrm{ml}$. 
Cyanide analysis in cassava leave extract: the quantification of free cyanide in the aqueous extract obtained was conducted using the spectrophotometer method described by Brito et. al. (2013).

Obtaining monospecific cultures of $\boldsymbol{H}$. contortus. the research was carried out with the authorization of the Ethics and Use of Animals Committee of the institution, under protocol $n^{\circ}$ 013/2012, as follows:

According to the technique described by Gordon and Whitlock (1939), a donor (A) of H. contortus was selected. It was an adult, one-year-old lamb, naturally infected by nematodes of the Trichostrongylidae family with a count of 23,000 eggs per gram of feces (EPG). The donor (A) was euthanized, its abomasum was immediately extracted, and its internal content was poured into vats and with the aid of spatulas, the adult $H$. Contortus was collected and kept in phosphate-buffered saline (PBS) solution at the temperature of $37^{\circ} \mathrm{C}$ (Witola et al, 2016). In order to obtain H. contortus eggs, two six-month-old lambs were donators (B). Previously, both animals were subjected to a parasite purging process, and the absence of gastrointestinal parasites was confirmed by coprological tests. The adult helminths collected from the donor lamb $\mathbf{A}$ were introduced into the abomasum of the donor lambs $\mathbf{B}$, according to the surgical technique described by Paiva et al (1999). To confirm the presence of $H$. contortus eggs, several coprological tests were performed on fecal samples collected from the animals 25 days after the procedure. During the entire experimental period, the animals remained individually housed in pens, free from environmental contamination. To avoid external contamination, the pens were cleaned and sanitized daily with detergents and sodium hypochlorite. To obtain the third-stage larvae (L3) for the tests, the feces were collected in bags made of cotton fabric specially developed for their collection. Following the guidelines of Tissier et al (1975), these collecting bags were fixed for 12 hours directly in the animal's anal region. The material obtained was used to perform the coprological exams, following the methodology described by Roberts and O'Sullivan (1950), where feces and vermiculite were mixed in equal volume and placed in cylindrical glass containers with a capacity of $500 \mathrm{ml}$, but only half the container being used. With the aid of a glass rod, a hole was made in the center of the material to allow oxygenation. The container remained partially covered, and a piece of thick string was placed over its diameter to ensure that the container remained ajar. Once a day, distilled water was sprinkled over the material to keep the culture moist. The containers were labeled with the date and then incubated in a B.O.D chamber at the temperature of $28^{\circ} \mathrm{C}$ for 7 days. After the incubation period, the L3-stage larvae were recovered using the Baermann Technique (Witola et al, 2016).

Sheathing and larval motility test of third-stage larvae: L3-stage larvae were sheathed in $0.15 \%$ sodium hypochlorite solution at $37^{\circ} \mathrm{C}$ for $5 \mathrm{~min}$ (Almeida, 2018). Then, the larvae were washed five times in sucrose solution (12\%) through centrifugation process to remove the remains of the sheaths and possible dead larvae (Paiva et al, 2001). The number of larvae by milligram was estimated by diluting L3-stage larvae in distilled water and doing the counting under an optical microscope. The larval motility test described by Hubert and Kerboeuf (1984) and Preston et al (2015), with adaptations, was used to conduct the in vitro bioassays. The unsheathed L3-stage larvae were added to 12-well culture plates (100 L3-stage larvae per well), followed by serial concentrations of 5.2 to $80.0 \mathrm{mg}$ of cassava leaves $\mathrm{ml}^{-1}$, being each well adjusted with distilled water for a total volume of $2 \mathrm{ml}$ per well. A distilled water solution 
of Merial Ivomec ${ }^{\circledR}$ at the concentration of $0.01 \%$ was used as a positive control (FCL), and distilled water as a negative control (NCW). Subsequently, the plates were homogenized for 3 minutes and placed in a bacterial incubator at $28^{\circ} \mathrm{C}$ for 24 hours. After this period, the mobile (viable) and immobile (inviable) larvae were counted with the aid of a stereomicroscope. All bioassays were performed in triplicate. The motility index was calculated for each group of different concentrations and positive and negative control, applying the Equation I:

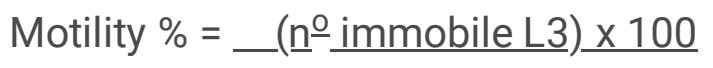

\section{Equation I}

Total $n^{\circ}$ of $L 3$ in the treatment

\section{Where:}

Unviable: the immobile L3-stage larvae

Viable: the mobile L3-stage larvae

Statistical analysis: the lethal concentration (LC) of the aqueous extract of fresh leaves of cassava ( $M$. esculenta) enough to paralyze all larvae was estimated from the results, where the concentrations were transformed into Log10. Data from the larval motility index were compared using ANOVA and Tukey test, where the significance level adopted was $0.05 \%$. All analyzes were performed using the software BioEstat ${ }^{\circledR}$.

\section{Results And Discussion}

Sheep farmers believe, from experience and observation, that there is a reduction in the egg load of intestinal parasites, including Haemonchus contortus, in animals fed with cassava. The researchers decided to investigate the hypothesis that this reduction occurs due to the presence of free cyanide in the fresh cassava leaf extract that was prepared at the same time as the obtention of $H$. contortus for the mobility test of L3-stage larvae.

Table 1 presents the results of the controlled bioassay, in which 100 isolated L3-stage larvae (in triplicate) were subjected to variations in the concentration of the aqueous extract of fresh cassava leaves. As elaborated, the aqueous extract showed a concentration range of 0.22 to $3.44 \mu \mathrm{g}$ of $\mathrm{CN}^{-} \mathrm{ml}^{-}$.

Table 1 - Effect of the aqueous extract of fresh cassava leaves and cyanide (CN) concentration on the motility of a hundred L3-stage larvae of $H$. contortus (Average of 3 replicates). 


\begin{tabular}{|c|c|c|c|c|c|}
\hline \multirow{2}{*}{$\begin{array}{l}\text { Mass concentration of fresh cassava } \\
\text { leaves in the water extract } \\
\mathrm{mg} \mathrm{x} \mathrm{ml}^{-1}\end{array}$} & \multirow{2}{*}{$\begin{array}{c}\mathrm{CN}^{-} \\
\text {Concentration } \\
\mu \mathrm{g} \mathrm{x} \mathrm{ml}^{-1}\end{array}$} & \multicolumn{3}{|c|}{$\begin{array}{l}\text { Number of mobile } \\
\text { larvae per } \\
\text { repetition }\end{array}$} & \multirow{2}{*}{$\begin{array}{c}\text { Mobility } \\
\text { reduction } \\
\text { Mean and } \\
\text { standard } \\
\text { deviation (*) }\end{array}$} \\
\hline & & R1 & R2 & $\overline{\mathrm{R} 3}$ & \\
\hline 5,2 & 0,22 & 95 & 92 & 94 & 93,67 \\
\hline 10,0 & 0,43 & 70 & 65 & 60 & 65,00 \\
\hline 20,0 & 0,86 & 40 & 50 & 48 & $46,00 \mathrm{c}$ \\
\hline 40,0 & 1,72 & 20 & 25 & 22 & $22,34 \mathrm{~d}$ \\
\hline 80,0 & 3,44 & 0 & 0 & 0 & $0,00 \mathrm{e}$ \\
\hline Ivomec $\AA(F C L)$ & $0,01 \%$ & 04 & 03 & 0 & $2,34 \mathrm{e}$ \\
\hline Distilled water NCW) & 0,00 & 98 & 99 & 96 & $97,6624 a$ \\
\hline
\end{tabular}
$(*):$ Equa
(Tukey test).

The results confirmed the toxic effect on the sheathed larvae of $H$. contortus, an effect proportional to the concentration of extract of fresh cassava leaves. From the data presented in Table 1, a curve was fitted relating the mobility of L3-stage larvae with the concentration of cassava leaf extract. The curve that best fit the results was the logarithmic equation $y=-33.39 \ln (x)+40.517, R^{2}=0.996$ (Figure 1), with a positive and significant correlation of the larvae immobility with the increasing free cyanide concentration in the cassava leaf extract. The equation highlights that the greatest effect was caused between 0.0 and $0.5 \mu \mathrm{g}$ of $\mathrm{CN} \mathrm{ml}^{-1}$ when about $50 \%$ of L3-stage larvae lost their mobility. The curve becomes less accentuated with the increase in free cyanide content from this concentration, but it is not asymptotic before affecting the total of larvae, equaling the control of the commercial product based on ivermectin, which had an immediate impact on the larvae mobility.

The equation allowed us to calculate the dose that may cause total paralysis of one hundred L3-stage larvae $\left(\mathrm{LD}_{100}\right)$, which approximately occurred at $3.5 \mu \mathrm{g}$ of $\mathrm{CN}^{-} \mathrm{ml}^{-1}$, corresponding to $80 \mathrm{mg}$ of cassava leaves $\mathrm{ml}^{-1}$ or $80 \mathrm{~g} \mathrm{l}^{-1}$. This result agrees with the results from Sokerya, (2009), who states that the consumption of cassava leaves can reduce the number of intestinal parasites in sheep, but it also may contradict the author's conclusion that a dose of $170 \mathrm{mg}$ of HCN per $\mathrm{kg}$ can be innocuous as an anthelmintic. Onwuka et al, (1992) and Sokerya, (2009) reported the need for 246 to $248 \mathrm{mg} 100 \mathrm{~g}$ of cyanide to achieve similar effects.

It is noteworthy that cassava leaves may vary in cyanide content depending on the cultivar or variety, age, and time of year (Ravindran, 1995). The results obtained in this experiment partially agree with those of Suteky and $\mathrm{Ji}$ (2019), where $47.87 \%$ of the larvae were immobilized with $12.5 \mathrm{mg} \mathrm{ml}$ of cassava leaf extract; this difference can be attributed to the fact that the authors were based on larval development and not on larval motility. 
Al-Rofaai et al (2012) reported efficiency of $57.33 \%$ on L3-stage larvae by an extract of $12.5 \mathrm{mg}$ of cassava leaf $\mathrm{ml}^{-1}$, and that it would be necessary $22 \mathrm{mg}$ to achieve total larvae immobility. Although even less than the $80 \mathrm{mg}$ we found to immobilize all L3-stage larvae, it is necessary to consider that the experiment did not eliminate the effect of solvents used in the cassava leaf extract preparation. The author evaluated solvents, in addition to tannins, alkaloids, flavonoids, steroids, and phenols. The solvents used were hexane, chloroform, ethyl acetate, and methanol (80\%), precisely the ones that presented the best effect against the larvae, so it is impossible to separate the cyanide effect from the effect of the solvents used.

The same use of solvents was observed in several other studies carried out to evaluate the anthelmintic effect of cassava extracts. Marie-Magdeleine et al (2010), before processing the extract, removed the cyanogen glycosides and then dehydrated the extract. The resulting powder was then diluted with three different extraction solvents, dichloromethane, methane, and water, especially because the author focussed on the effects of tannins on the parasites.

In our experiment, we used only water, as the purpose was to evaluate the cassava leaves naturally, with minimal chemical interventions, so that we could have the closest scenario to the ingestion process of the plant leaves in the animal's rumen, ensuring the presence of all its compounds, even those not soluble in water.

In several studies carried out to evaluate the anthelmintic effect of cassava leaf extract, the authors use different solvents for the extraction, aiming to study the effect of phenolic compounds. Al-Rofaai et al (2012) evaluated tannins and phenols, substances known for their antiparasitic effects, not only against H. contortus, but also against other nematode species. Alkaloids, flavonoids, steroids, and phenols, were also evaluated for the same purpose (Sokerya 2009; Marie-Magdeleine et al, 2010; Al-Rofaai et al, 2012; Suteky and Ji, 2019; Constant, 2020). In order to assess the effect of tannins on parasites, MarieMagdeleine et al (2010) removed the cyanogen glycosides, and the resulting powder from the process was diluted with dichloromethane, methane, and water.

Another experiment carried out in Malaysia by Sokerya (2009) explores the potential of the cyanide present in cassava leaves, although focusing on goats and not sheep. The author evaluated the anthelmintic effects of cassava fed to animals contaminated with $\mathrm{H}$. contortus but used cassava leaves in different ways such as fresh, ensiled, and dehydrated. The count of eggs present in the feces of these animals was conducted after a specific period after the ingestion and showed positive results in all groups in which the animals were fed with cassava, but mainly with the consumption of fresh leaves. The authors justify that they did not carry out the detoxification of cassava by drying, as carried out by MarieMagdeleine et al. (2010), precisely because the objective was to relate the forms of feeding the animals with cassava and their respective responses to the parasite load. However, the authors emphasize that the risk of poisoning the animal with cyanide should not be neglected, which is why they measured the amount of $\mathrm{HCN}$ present in the plants used, which presented $585 \mathrm{mg}^{-} \mathrm{CN}^{-}$per $\mathrm{kg}$ of fresh leaves, and 170 $\mathrm{mg}$ of $\mathrm{CN}^{-}$per $\mathrm{kg}$ of silage made with the same leaves. The author also highlighted that the values 
observed are within the tolerance limits for ruminants, which is 2 to $6 \mathrm{mg} \mathrm{kg}$ of the animal's live weight Onwuka et al, (1992), reducing the risk of intoxication.

Although our bioassay confirms that the cyanide present in cassava leaves, and not only its phenolic compounds, has a direct effect against $H$. contortus larvae, these results must be evaluated and adjusted by feeding fresh cassava leaves to sheep.

The comparison of results with the literature showed the lack of information on the anthelmintic potential of cassava leaves through aqueous extract or that that highlights the cyanogenic compounds of the plant, although the literature pointing out the risks of cyanide consumption for human and animal health is very common.

The review also highlighted that the focus of anthelmintic use of cassava leaves for sheep and goats feed has always been hypothesized by the effect of the phenolic compounds, such as tannins, as reported in the literature for their antiparasitic effects, not just against $H$. contortus, but to other nematode species as well. Also, it would be important to compare the effect of cyanogenic and phenolic compounds, with and without the use of solvents in the same in vitro bioassay.

On the other hand, the research started from the principle that, if the anthelmintic effect is proven, the use of leaves is easier and more viable, since it is not necessary to use the cassava roots, which have commercial value, or the branches, which are used as planting material. Leaves can be obtained uninterruptedly throughout the year or the summer in some regions of southern South America, through pruning, as the literature confirms that up to 3 prunings in 12 months of cultivation do not affect root yields.

If cassava leaves contain compounds from the phenolic group, such as tannins and saponins, in addition to cyanogenic glycosides (Tao et al, 2019), they also have a high nutritional value (Pereira et al, 2018). The use of cassava leaves to feed sheep or goats is possible (Vilpoux et al. 2013) and may also be a powerful tool, diversifying its antiparasitic power and preventing the occurrence of resistance to the present anthelmintic principles.

This type of local use could also add value to the production of cassava leaves, as assessed by Sagrilo et al. (2001), who weighted the leaves harvested in commercial cassava plantations for starch extraction, with 12 and 24 months of cultivation of the 5 main cultivars planted. The authors found out an average production of fresh leaves of 2.4 tonnes ha- ${ }^{-1}$, but ranging from 1.8 to 7.5 tonnes ha ${ }^{-1}$, available throughout the year, with higher production at the beginning of the cultivation cycle and in the summer months in Brazil (September to May). Currently, this volume of good-quality protein material remains without use in the field.

\section{Conclusions}


Considering that it is impossible to rule out the antiparasitic effect of phenolic compounds, and even though the investigation of the cyanogen compounds from cassava leaves was never approached indepth, the bioassay was planned with a different concept and perspective in the control of endoparasites, as an aqueous extract and targeting $H$. contortus larvae mobility as an index of parasitosis and as a target for the evaluation of anthelmintic substances.

It was possible to conclude that the aqueous extract of fresh cassava leaves was able to immediately inhibit the movement of one hundred L3-stage larvae $\left(L D_{100}\right)$ of $H$. contortus with a concentration of 3.5 $\mu \mathrm{g}$ of $\mathrm{CN}^{-} \mathrm{ml}^{-1}$, which corresponds to $80 \mathrm{mg}$ of leaves per $\mathrm{ml}^{-1}$ or $80 \mathrm{~g}$ per liter.

The results obtained are promising but should be complemented with direct feeding tests with fresh, dried, and ensiled leaves, accompanied by dosing the free cyanide, which is generated by the rumen digestive process and circulates with the blood to reach the intestinal parasites, but also to study the effect on hematophagous ectoparasites such as ticks. Tests should be also carried out with a longer duration to verify the possibility of resistance to cassava compounds occurring over time. Only after these tests, rural producers will recommend the use of cassava leaves as natural anthelmintic medicine.

\section{References}

AL-ROFAAI, A., RAHMAN, W.A., SULAIMAN, S.F., YAHAYA Z.S. In vitro ovicidal and larvicidal activity of methanol leaf extract of Manihot esculenta (cassava) in resistant and susceptible strains of Trichostrongy/us colubriformis. Parasitologia Veterinária, v. 190, p.127-135, 2012, https://doi.org/10.1016/j.vetpar.2012.05.028.

AL-ROFAAI, A., WAHAB, A., RAHMAN, W.A., AND SULAIMAN, A. In vitro anthelmintic activity of cassava (Manihot esculenta) extract on Trichostongyloid larvae. Veterinary Parasitology, v.190, n.1-2, p. 127-135, 2012, available at: <www.semanticscholar.org/paper/In-vitro-anthelmintic-activity-of-Cassava-(-ManihotAl-Rofaai-Rahman/f46176d7254118dcc3aadb6c2b4cb267da7a4be1>

ALMEIDA, B. H. In vitro antihelmintic potential of lectin (Jacalina/ArtinM) Artocarpus heterophyllus LAM preparation in vitro isolated from seeds of Artocarpus heterophyllus LAM. on Haemonchus contortus larvae. Thesis (Bacharel in Biotechnology) - Biological and Health Sciences Center and the Universidade Rural do Semiárido. Mossoró, p.44, 2018. (In Portuguese). Available at: < http://repositorio.ufersa.edu.br/handle/prefix/3211>. Consulted in: October 26, 2021.

ATHANASIADOU, S., KYRIAZAKIS, I., JACKSON F., COOP, R.L. Direct anthelmintic effects of condensed tannins towards different gastrointestinal nematodes of sheep: in vitro and in vivo studies. Veterinary Parasitology, v.99, p.205-219, 2009, https://doi.org/10.1016/S0304-4017(01)00467-8.

BRIK, K., HASSOUNI, T., ELKHARRIMA, K., BELGHYTI, D. A survey of Haemonchus contortus parasite of sheep from Gharb plain, Morocco. Parasite Epidemiology and Control, v. 4, p.e00094, 2019, https://doi.org/10.1016/j.parepi.2019.e00094. 
BRITO, V.H.S.; RABACOW, A.P.M.; CEREDA, M.P. Classification of nine-month-old cassava cultivars by cyanide levels. Geneconserve, v.12, n.47, p. 35-49, 2013, available at $<$ https://www.researchgate.net/publication/257583819_Classification_of_nine_monthold_cassava_cultivars_by_cyanide_levels >. Consulted in: October 26, 2021.

CASTAÑEDA-RAMÍREZ,G.S., TORRES-ACOSTA, J. F.J., SANDOVAL-CASTRO, C. A., BORGES-ARGÁEZ, R., CÁCERES-FARFÁN, M., MANCILLA-MONTELONGO,G. MATHIEU,C. Bio-guided fractionation to identify Senegalia gaumeri leaf extract compounds with anthelmintic activity against Haemonchus contortus eggs and larvae, Veterinary Parasitology, v. 270, p. 13-19, 2019, https://doi.org/10.1016/j.vetpar.2019.05.001 .

CASTAÑEDA-RAMÍREZ, G.S., TORRES-ACOSTA, J.F.J., SANDOVAL-CASTRO, C.A., GONZÁLEZ-PECH, P.G., PARRA-TABLA, V.P., MATHIEU, C. Is there a negative association between the content of condensed tannins, total phenols, and total tannins of tropical plant extracts and in vitro anthelmintic activity against Haemonchus contortus eggs? Parasitol Res. v.116, p.3341-3348, 2017, https://doi.org/10.1007/s00436017-5650-4.

CONSTANT, M. Evaluation in vitro de l'effet de la granulation sur les propriétés AH de TC issus de plantes tropicales. Sciences du Vivant [q-bio], 2016, https://hal.inrae.fr/hal-02796411

GENSA, U. Review on Cyanide Poisoning in Ruminants. Journal of Biology, Agriculture and Healthcare, v.9, n.6, 2019, https://doi.org/10.7176/JBAH

GORDON, H. McL; WHITLOCK, A.V. A new technique for counting nematode eggs in sheep feces. Journal Council Scientific Industry Research Australia, v. 12, p. 50-52, 1939, available at: https://publications.csiro.au/rpr/pub?list=BRO\&pid=procite:21259a33-8a8e-4add-9315f8338091a3e6

TAO, H., CUI, B., ZHANG, H., BEKHIT, A. E. \& LU, F. Identification and characterization of flavonoids compounds in cassava leaves (Manihot esculenta Crantz) by HPLC/FTICR-MS. INTERNATIONAL JOURNAL OF FOOD PROPERTIES, v.22, n.1, p.1134-1145,

2019, https://doi.org/10.1080/10942912.2019.1626879

HUBERT, J., KERBOUEF, D. A new method for culture larvae used in diagnosis of ruminant gastrointestinal strongylosis: comparison with fecal cultures. Canadian Journal of Comparative Medicine, v. 48, p. 63-71, 1984, available at <https: www.ncbi.nlm.nih.gov/pmc/articles/PMC1236007/ >

KAMARAJ C, RAHUMAN AA. Efficacy of anthelmintic properties of medicinal plant extracts against Haemonchus contortus. Research Veterinary Science, v.91, p.400-404, 2010, https://doi.org/10.1016/j.rvsc.2010.09.018

KEITH, R.K. The differentiation on the infective larvae of common nematodes parasites of cattle. Aust. J. Zool. v.1, p. 223-235, 1953, https://doi.org/10.1071/Z09530223 
MARIE-MAGDELEINE, C., MAHIEU, M., D'ALEXIS, S., PHILIBERT, L., ARCHIMEDE, H. In vitro effects of Tabernaemontana citrifolia extracts on Haemonchus contortus. Res Vet Sci. v.89, p.88-92, 2010. https://doi.org/10.1016/j.rvsc.2010.01.002.

MARIE-MAGDELEINE, C., UDINO, L., PHILIBERT, L., BOCAGE, B., ARCHIMEDE, H. In vitro effects of Musa $x$ paradisiaca extracts on four developmental stages of Haemonchus contortus. Res Vet Sci. v. 96, p.12732, 2014, https://doi.org/10.1016/j.rvsc.2013.12.004

MARIE-MAGDELEINE, C., UDINO, L., PHILIBERT, L., BOCAGE, B., ARCHIMEDE, H. In vitro effects of Cassava (Manihot esculenta) leaf extracts on four development stages of Haemonchus contortus. Vet Parasitol, v.173, p.85-92, 2010, https://doi.org/10.1016/j.vetpar.2010.06.017 .

MINATCHY, N., MARIE-MAGDELEINE, C., GARIN, M., Nimirf, F., Romil-Granville, D, Philibert, L., Calif, V., Bambou, J., Archimède, H. Nutraceutical properties of Leucaena leucocephala, Manihot esculenta, Cajanus cajan and a foliage blend in goat kids infected with Haemonchus contortus. Sci Rep 10, n. 9969, 2020, https://doi.org/10.1038/s41598-020-66870-5

MOLENTO, M.B., PRICHARD, R.K. Effect of multidrug resistance modulators on the activity of ivermectin and moxidectin against selected strains of Haemonchus contortus infective larvae. Pesquisa Veterinária Brasileira [online]. v. 21, n. 3, 2001, https://doi.org/10.1590/S0100-736X2001000300004.

ONWUKA, C. F. I., A. O. AKINSOYINU AND O. O. TEWE. Role of sulfur in cyanide detoxification in ruminants. Small Rumin. Res. v.8, p. 277-284, 1992, https://doi.org/10.1016/0921-4488(92)90209-M

PAIVA, F., SATO, M. O., JENSEN, J. R., BRESSAN, M. C. R. V. Surgical transfer technique for establishment of infection by adult forms of Haemonchus placei. In: Seminar on Veterinary Parasitology of Mercosur Countries and I Symposium on Integrated Control of Bovine Parasites, 1999, 2 Salvador. 2 . (In Portuguese).

PAIVA, F., SATO, M.O., ACUNA, A.H., JENSEN, J.R., BRESSAN, M.C.R.V. Ivermectin resistance found in Haemonchus placei and Cooperia punctata in cattle. Veterinary Time, March/April, v.120, p.29-34, 2001. (In Portuguese). Available at < http://helminto.inta.gob.ar/pdf\%20Resistencia/RESISTENCIA\%20PAIVA.PDF.

Brazilian Archive of Veterinary Medicine and Animal SciencePEREIRA, L.C., ÍTAVO, L.C.V., MATEUS, R.G., ROSA, M.O., MACENA, I., REIS NETO, J.F., BARBOSA-FERREIRA, M., CARVALHO, C.M.E. Economic aspects of the use of fresh cassava (Manihot esculenta Crantz) aerial part for the nutrition of confined and semiconfined lambs. Arquivo Brasileiro de Medicina Veterinária e Zootecnia [online]. v. 70, n. 01, p. 279-286, 2018. (In Portuguese).https://doi.org/10.1590/1678-4162-9281 .

PRESTON, S., JABBAR, A., NOWELL, C., JOACHIM, A., RUTTKOWSKI, B., BAELL, J., CARDNO, T., KORHONEN, P.K., PIEDRAFITA, D., ANSELL, B.R., JEX, A.R, HOFMANN, A., GASSER, R.B. Low cost whole- 
organism screening of compounds for anthelmintic activity. Int J Parasitol. v.45, p.333-343, 2015, https://doi.org/10.1016/j.ijpara.2015.01.007 .

RAVINDRAN, V. Preparation of cassava leaf products and their use as animal feeds. In: Roots, Tubers, Plantains, and Bananas in Animal Feeding (Eds. D. Machin and S. Nyvold). FAO Animal Production and Health Paper, n. 95, 111 pp, 1995, available at < https://www.fao.org/3/t0554e/t0554e08.htm >

ROBERTS, F.H.S., O'SULLIVAN, J.P. Methods for egg counts and larval cultures for strongyles infesting the gastrointestinal tract of cattle. Australian Journal of Agriculture Research, v.1, p.99-102, 1950, https://doi.org/10.1071/AR9500099

SAGRILO, E., VIDIGAL FILHO, P. S., PEQUENO, M. G. \& RIMOLDI, F. Dimensioning of agricultural byproducts of cassava (Manihot esculenta, Crantz). In: Cereda, M.P. \& Vilpoux, O.F. Management, use and treatment of by-products from the industrialization of cassava, v.46, n.2, p.291-304, 2001. (In Portuguese).

(Manihot esculenta, Crantz). In: Cereda, M.P. \& Vilpoux, O.F.

SHEATHER, A.L. The detection of intestinal protozoan and mange parasites by a flotation technique J. Comp. Pathol. v.36, p. 266-275, 1923, https://doi.org/10.1016/S0368-1742(23)80052-2

SOKERYA, S. The effect of cassava foliage (Manihot esculenta) on gastrointestinal parasites of small ruminants in Cambodia. Doctoral diss. Dept. of Biomedical Science and Veterinary Public Health, SLU. Acta Universitatis agriculturae Sueciae vol.43,2009, available at $<$ https:// pub.epsilon.slu.se/2010/1/Thesis.pdf >

SQUIRES, J.M., FERREIRA, J.F., LINDSAY, D.S., ZAJAC, A.M. Effects of artemisinin and Artemisia extracts on Haemonchus contortus in gerbils (Meriones unguiculatus). Vet Parasitol. v.175, p.103-108, 2011, https://doi.org/10.1016/j.vetpar.2010.09.011 .

SUTEKY, T.; JI, D. The Use of Melastoma malabatricum and Manihot esculenta extract as natural anthelmintic on the Performance of Kacang goat. $6^{\text {th }}$ International Conference on Sustainable Agriculture, Food and Energy, Indonesia. v. 347, ed. 012015, p. W5558A, 2019, https://doi.org/10.1088/1755$1315 / 347 / 1 / 012015$.

TEO, C.R.P.A., PRUDENCIO, S.H., COELHO, S.R.M. MAURO, S. Obtaining and physicochemical characterization of cassava leaf protein concentrate. Brazilian Journal of Agricultural and Environmental Engineering, 14, n.9, p.993-999, 2010. (In Portuguese) https://doi.org/10.1590/S141543662010000900012

TISSIER, M., BECHET, G., MOLÉNAT, G., DACHEUX, P., MAQUERE, M. Appareils de collecte totale des fèces pour agneaux en allaitement ou a l'engrais et pour brebis. Annales de Zootechnie, INRA/EDP Sciences, 
v.24, p.595-602, 1975,

https://doi.org/10.1051/animres:19750320

VILPOUX, O.F., YOSHIHARA, P. H. F., PISTORI, H., ÍTAVO, L. C. V., \& CEREDA, M. P. (2013). Raising sheep with whole cassava-based feed with appropriate technology for family farming. Brazilian Journal of Regional Management and Development, 9(1). (In Portuguese). Available at: https://rbgdr.net/revista/index.php/rbgdr/article/viewFile/876/322. Consulted on October 26, 2021.

WITOLA, W.H., MATTHEWS, K., MCHUGH, M. In vitro anthelmintic efficacy of inhibitors of phosphoethanolamine Methyltransferases in Haemonchus contortus. Int J Parasitol Drugs Drug Resist. v.6, p.44-53, 2016, https://doi.org/10.1016/j.ijpddr.2016.01.002 .

\section{Figures}

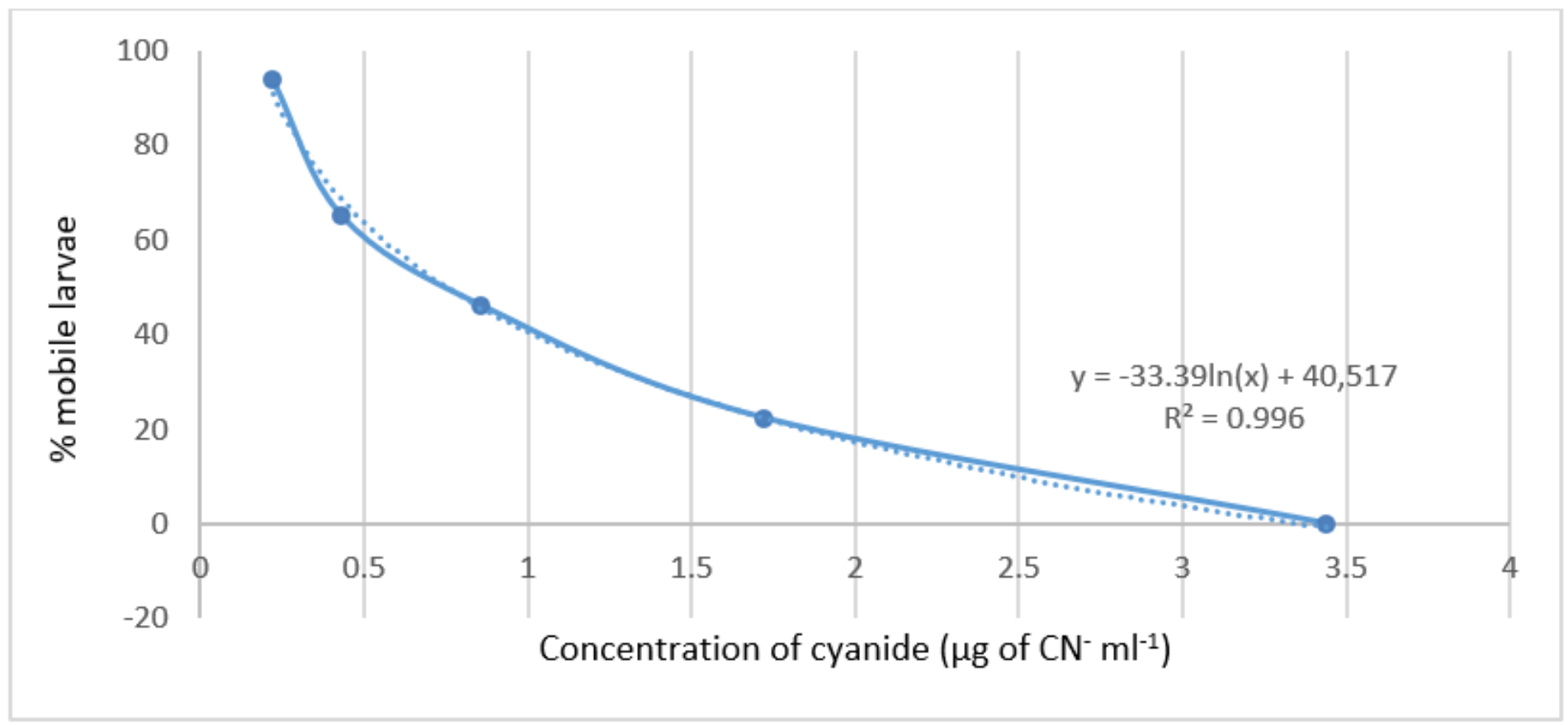

\section{Figure 1}

Effect of $\mathrm{CN}$ - concentration (mg ml-1) in aqueous extract of fresh leaves of cassava (Manihot esculenta) and the reduced motility of L3-stage larvae of $\mathrm{H}$. contortus (average of 3 replicates). Discontinuous line: obtained values; Continuous line: fitted equation 